\title{
Dispersion and Modeling of Gaseous Pollutants Released From 12 Hp Diesel Engines at Some Selected Sites in North Central Nigeria
}

\author{
A.A Tyovenda ${ }^{1}$, J.U Ugwuanyi $^{2}$, T. Sombo ${ }^{3}$, F.O Anjorin ${ }^{4}$ \\ ${ }^{1,2,3}$ Department of Physics, Federal University of Agriculture, Makurdi. Benue State-Nigeria \\ ${ }^{4}$ Department of Physics, University of Jos. Plateau State-Nigeria
}

\begin{abstract}
This work is aimed at quantifying the dispersion strength and environmental impacts of gaseous pollutants such as Carbon (II) oxide, Sulphur (IV) oxide and Hydrogen sulphide emitted from $12 \mathrm{hp}$ Diesel powered water-cooled engine at some selected sites in North central Nigeria. A real time analysis was adopted in monitoring these sources by the use of ALTAIR Multi- gas detector. The estimated emission rates of $139.04 \mathrm{mg} / \mathrm{s}, 4.227 \mathrm{mg} / \mathrm{s}$ and $2.335 \mathrm{mg} / \mathrm{s}$ were obtained for $\mathrm{CO}, \mathrm{SO}_{2}$ and $\mathrm{H}_{2} \mathrm{~S}$ respectively. The average monitored concentration of $\mathrm{CO}, \mathrm{SO}_{2}$ and $\mathrm{H}_{2} \mathrm{~S}$ for dry season at $5.0 \mathrm{~m}$ from these sources are $4.0 \mathrm{mg} / \mathrm{m}^{3}, 0.185$ and 0.270 respectively while that of rainy season at $5.0 \mathrm{~m}$ from these sources are $2.272 \mathrm{mg} / \mathrm{m}^{3}, 0.197 \mathrm{mg} / \mathrm{m}^{3}$ and $0.174 \mathrm{mg} / \mathrm{m}^{3}$ respectively. The respective coefficient of regression, $\mathrm{R}^{2}$ for $\mathrm{CO}, \mathrm{SO}_{2}$ and $\mathrm{H}_{2} \mathrm{~S}$ for measured and modeled concentration from these sources are 0.874, 0.960 and 0.968. These depict measured and modeled $\mathrm{CO}_{2} \mathrm{SO}_{2}$ and $\mathrm{H}_{2} \mathrm{~S}$ concentrations correlating highly. Based on National Ambient Air Quality Standards, the immediate microenvironments $(<5.0 \mathrm{~m})$ of these sources are unsafe. It is therefore recommended that exposure to these sources be grossly reduced by relevant environmental management agencies enacting environmental policies that regulate the duration of exposure to these sources so as to reduce the health impact of these emissions. Also, since these pollutants are generated in combustion, modifications to the combustion process itself by ensuring greater air to fuel mixture in the combustion chamber design can be quite effective in reducing their formation.
\end{abstract}

Keywords: Diesel, emissions, pollutants, concentration, Gaussian, gaseous and Dispersion.

\section{Introduction}

International Agency for Research on Cancer, IARC, (2015) reported that anthropogenic activities have led to increases in the level of many air pollutants that have debilitating effects on environmental and public health. Among such are emissions from the exhaust of Diesel Engines used in silo filling, heavy sawing, large grinding mills, and block molding. These activities are common place in developing countries such as Nigeria and the most commonly used diesel engine type for these activities is 12 Horse Power Water-cooled Diesel Engine.

In recent years, several epidemiological studies have emerged showing several negative health effects associated with short-term and long-term exposure to air pollutants (Armstead,1988). But according to Klepeis et al., (2007), data on human exposure to air pollutants occurring in ground-level outdoor environments within a few meters of point sources is anecdotal.

By observations, these emissions evolve with its own temporal and spatial scales, which could considerably vary from a composite to another (Dede, 2008), and the spatial representativeness of an emission source relates to the variability of concentrations of a specific pollutant around it (Anno, 2013; Piersanti et al., 2013). The concentration of an emission at any location is an interplay of several factors such as the emission rate, the downwind distance of the receptor from the emission source, and the atmospheric turbulence (AbdelRahman, 2008; ECA, 2016). Also, the dispersion of any portion of the atmosphere is a function of its location and time (Jay et al., 2002). Sometimes the atmosphere enhances dispersion, and in such cases the concentration of pollution is generally decreased. At other times, however, the atmosphere may impede dispersion; resulting in the accumulation of pollutants near the source and concentrations will rise (NAQMP, 2016). In fact, thermally stable atmospheric conditions and their associated shallow mixing depths are known for inhibiting the dispersion of urban pollution (e.g.Perrino et al., 2008; Belušić et al., 2015; Grundstrom et al., 2015; Chambers et al., 2015a). This has made it necessary to discover and understand the links between emission sources, the atmospheric stability conditions and air quality deterioration that results. For the effects of dispersion on any pollutants to be quantified, its' movement has to be related to the vortexes characterizing the air volume in which the pollutants are introduced. If the vortex dimension characterizing the emission is bigger than the one characterizing the atmosphere around, the dilution process is very rapid and efficient; on the other hand, when 
the vortex dimension of the emission is smaller, the advective transport is predominant over the turbulent diffusion process, thus giving higher concentration (Antonacci, 2005).

According to literatures, there is long list of pollutants released into the atmosphere from the exhaust of diesel engine. Among these pollutants are Carbon (II) oxide, Sulphur (IV) oxide and Hydrogen sulphide (IARC, 2013a). These cause severe air quality degradation, most especially within the microenvironments of the engines which is highly hazardous to both human and public health. Based on several epidemiological studies, exposure to diesel emissions is a major cause of several forms of cancer. As a matter of fact, emissions from exhausts of diesel engines have been classified by International Agency for Research on Cancer, IARC (2015) as Group 1 carcinogen (IARC, 2013a). It causes lung cancer and is associated with an increased risk for bladder cancer.

However, in-situ measurements may furnish us with quantitative information about ambient concentrations status and deposition at specific locations and times; they may be handicapped in giving clear understanding of the causes of the air quality problem. Hence, the need for adopting modeling approach which can give a more complete deterministic account of the air quality problem, including an analysis of factors and causes (emission sources, meteorological processes, and physical and chemical changes), and some advisory on the implementation of mitigation measures (Daly and Zannetti, 2007; Nguyen, 2014). This work seeks to quantify the effects of the atmosphere's dispersion strength on pollutants' concentrations emitted from $12 \mathrm{Hp}$ Diesel Engine and evaluate the applicability of Gaussian plume model in capturing the real dispersion feature of these pollutants; the present research is limited to validation of the model and its impact on air quality.

\section{Experimental Method/Analysis}

\subsection{The study area}

North Central Nigeria loosely known as Middle Belt; includes Benue State, Kogi State, Kwara State, Nasarawa State, Niger State, Plateau State and the Federal Capital Territory whose respective capitals are; Makurdi, Lokoja, Ilorin, Lafia, Minna, Jos and Abuja as shown in figure 1. The North Central Nigeria is located at an elevation of 115 meters above sea level. Its coordinates are $80^{\prime} 0^{\circ} 0$ ' $\mathrm{N}$ and $8^{0} 0^{\prime} 0^{\prime}$ ' $\mathrm{E}$ DMS (in Degree Minutes seconds). Its UTM position is LP88 and its Joint Operation Graphics reference is NC32-14. The sun rises at 08.06 and sets at 20:13 local time. The temperatures are above $18.54^{\circ} \mathrm{C}$ to $36.9^{\circ} \mathrm{C}$, and an annual rainfall of about $1,500 \mathrm{~mm}$ (59.1 in) with a single rainfall maximum in September. However, semi temperate weather conditions prevail on the highlands in central Nigeria above 1,200 meters $(3,937 \mathrm{ft})$ above sea level, namely the Jos Plateau. Temperature in Jos Plateau ranges between $21^{\circ} \mathrm{C}$ to $25^{\circ} \mathrm{C}$ which are cool all year round.

In Makurdi particularly, temperature is generally very high during the day, most especially in March and April. It records average maximum and minimum daily temperatures of $35^{\circ} \mathrm{C}$ and $21^{\circ} \mathrm{C}$ in summer and $37^{\circ} \mathrm{C}$ and $16^{\circ} \mathrm{C}$ in winter, respectively.

\subsection{Sampling Procedures.}

In this work, real time analysis was adopted to monitor and investigate the spatial and temporal variation of the gaseous pollutants such as Carbon (II) oxide, Sulphur (IV) oxide and Hydrogen sulphide emitted from some selected $12 \mathrm{Hp}$ Diesel Powered water cooled Engine sources shown in figure 2 in three cities in North Central Nigeria (see table 1). This was undertaken in Jos, Lafia and Makurdi which are respectively the State capital of Plateau, Nasarawa and Benue states for a period of one year at an average monitoring of once a week. The sampling was taken at any time of the day. Measurement frequency was such that monitoring was done in all the seasons so that all seasonal variations are assessed and included in computing annual average.

AIR multi-gas detector was used in measuring the ground level concentration of $\mathrm{CO}, \mathrm{SO}_{2}$ and $\mathrm{H}_{2} \mathrm{~S}$ concentrations respectively along the plume spread of 12 Horse power Diesel Engines used to power block molding machine as shown in figure 2. This Multi-Gas Detector was held at about $1.20 \mathrm{~m}$ from the ground level in the direction of plume spread in order to obtain concentration levels of these gaseous pollutants at the average breathing zone of the workers or people moving around these combustion sources. The measurement of the concentration of each pollutant was taken at the optimum load from all diesel engine exhausts at each site. These concentrations were measured at specified receptor points (i.e $1.0 \mathrm{~m}-5.0 \mathrm{~m}$ ) downwind the emission sources to determine the continuous and temporal variation of plume concentrations within their microenvironments. The locations of the selected sites obtained by using Geographical Positioning System (GPS) are presented in Table 1. The selection of these sites was based on their accessibility for monitoring, isolation from any known emission source(s), population density around them and the knowledge of existing deleterious effects emissions from these sources portend. Furthermore, the monitoring was carried out in areas where pollution problem exists or is expected, that is, mainly in urban areas.

\subsection{Model}

The dispersion model used to execute this work is the Gaussian Plume Model. This model was adopted because of its suitability for predicting the concentration of non-reactive pollutants downwind point emission sources. In 
order to find the dispersion of pollutants from diesel engine sources and its impact on air quality, in-situ measurements were taken downwind these sources. The 1-year monitored data was taken from selected sites to draw emission profiles. The model investigates the physical aspects concerning the atmospheric diffusion of the gaseous air pollutants with a deterministic method accounting of meteorological data too. The basic structure of these dispersion models is characterized by a database of algorithms that can describe in easy way the several composite phenomenon of the gas atmospheric dispersion. The modeling validation was carried out under Neutral atmospheric stability conditions. The input data of these simulation tools are the suitably treated meteorological parameters obtained from the weather stations distributed across the selected States, and the emission levels of the air pollutants.

The meteorological data were collected from Automatic Weather Operating System (AWOS) of the Nigeria Meteorological Agency (NIMET) which has installed the weather stations at the Jos airport, Heipang, Lafia Airport and Airforce Base Tattical Command, Makurdi. The anemometer heights for NIMET at Jos Airport and Lafia Pilot Station are respectively mounted at $4.5 \mathrm{~m}$ from the ground while that of Tattical Command Makurdi is $2.3 \mathrm{~m}$. However, since the plume advection heights from these emission sources are different from the anemometer heights, the wind profile law presented was employed to obtain the wind speed at the advection heights of the plume by extrapolation.

Gökçek and Bekdemir, (2007a) expressed a typical extrapolation comprising a power law:

$\frac{v}{v_{0}}=\left(\frac{h}{h_{0}}\right)^{a}$

' $v$ ' is the wind speed at the required height ' $h$ ', ' $v_{0}$ ' is wind speed at the original height ' $h_{0}$ ', and ' $a$ ' is the surface roughness coefficient. Akpinar and Akpinar, (2005) observed that 'a' lies in the range of 0.05-0.5.

However, the surface roughness coefficient, 'a' can be determined from the following expression Ucar, A. and Balo, F., (2009):

$$
\mathrm{a}=\frac{\left[0.37-0.088 \ln \left(v_{0}\right)\right]}{\left[1-0.088 \ln \left(\frac{h_{0}}{10}\right)\right]}
$$

\subsection{Mathematical Treatment}

If it is assumed that Fickian Diffusion, incompressible flow, and constant eddy diffusivities occur in all directions from the diesel engines' exhausts and for steady, continuous point source in 3-dimensions with negligible longitudinal diffusion, the advective-diffusion equation is given thus; (Fischer et al., 1979)

$$
\frac{\partial C}{\partial t}+\mathrm{u} \frac{\partial C}{\partial x}+\mathrm{v} \frac{\partial C}{\partial y}+\mathrm{w} \frac{\partial C}{\partial Z}=\mathrm{K}\left[\frac{\partial^{2} \mathrm{C}}{\partial \mathrm{x}^{2}}+\frac{\partial^{2} \mathrm{C}}{\partial \mathrm{y}^{2}}+\frac{\partial^{2} \mathrm{C}}{\partial \mathrm{z}^{2}}\right]
$$

where $\mathrm{K}$ is the constant eddy diffusivity

$\mathrm{u}, \mathrm{v}$ and $\mathrm{w}$ are the wind speed in $\mathrm{x}, \mathrm{y}$ and $\mathrm{z}$ directions,

$\mathrm{c}$ is the concentration of pollutants

Equation (3) presents the Left Hand Side as depicting the 3-dimensional advection term while the Right Hand Side constitutes the diffusion part of the transport problem and contains eddy diffusivity constant per direction. The emissions from $12 \mathrm{Hp}$ diesel engines are highly momentous, hence the diffusion transport in the downwind direction is smaller than the advection transport (Fischer et al.,1979); This modifies equation (3) to give;

$$
\mathrm{u} \frac{\partial C}{\partial x}+\mathrm{v} \frac{\partial C}{\partial y}+\mathrm{w} \frac{\partial C}{\partial z}=\mathrm{K}_{\mathrm{y}} \frac{\partial^{2} C}{\partial y^{2}}+\mathrm{K}_{\mathrm{z}} \frac{\partial^{2} C}{\partial z^{2}}
$$

since $K_{x} \frac{\partial^{2} C}{\partial x^{2}}=0$ and $\left(\frac{\partial C}{\partial t}=0\right)$

However, since the pollutants are moving only along the $\mathrm{x}$-axis at constant wind velocity, u, equation (3) can be further simplified:

$$
\mathrm{u} \frac{\partial C}{\partial x}=\mathrm{K}_{\mathrm{y}} \frac{\partial^{2} C}{\partial y^{2}}+\mathrm{K}_{\mathrm{z}} \frac{\partial^{2} C}{\partial z^{2}}
$$

When this simplified expression is solved, the solution to equation (3) becomes

$$
\mathrm{C}(\mathrm{x}, \mathrm{y}, \mathrm{z})=\frac{Q}{4 \pi \sqrt{K_{y} K_{z}}} \exp \left(\frac{-y^{2}}{4 \pi K_{y}(x / u}\right) \exp \left(\frac{-z^{2}}{4 K_{z}(x / u)}\right)
$$

where $\mathrm{Q}$ is the Emission rate or strength of source in $\mathrm{kg} / \mathrm{s}$.

The generalized equation for a continuous point-source plume will take the form:

$$
\mathrm{C}(\mathrm{x}, \mathrm{y}, \mathrm{z}, \mathrm{H})=\frac{Q}{2 \pi u \sigma_{y} \sigma_{z}}\left(\frac{-y^{2}}{2 \sigma^{2} y}\right)\left[\exp \left(\frac{-(z-H)^{2}}{2 \sigma^{2} z}\right)+\exp \left(\frac{-(Z-H)^{2}}{2 \sigma_{z}{ }^{2}}\right)\right]
$$

The effective height of emission,

$$
\mathrm{H}=\mathrm{h}_{\mathrm{s}}+\Delta h
$$

where $\mathrm{h}_{\mathrm{s}}$ is the physical emission source's height in metres

$\Delta \mathrm{h}$ is the plume rise in metres 
For emissions from the exhaust of diesel engines, the effective plume rise is not significant, more so that the plume is ejected horizontally for sources without stacks as shown in figure 2 (i.e $\mathrm{H}=0$ ), equation (7) reduces to: (Turner, 1970)

$$
\mathrm{C}(\mathrm{x}, 0,0,0)=\frac{Q}{2 \pi u \sigma_{y} \sigma_{z}}
$$

where

$\sigma_{\mathrm{y}}$ : lateral dispersion coefficient $(\mathrm{m})$

$\sigma_{\mathrm{z}}:$ vertical dispersion coefficient $(\mathrm{m})$;

$\mathrm{u}$ is the mean wind speed at the point of advection of plume in $\mathrm{m} / \mathrm{s}$;

$\mathrm{C}(\mathrm{x}, 0,0,0)$ is the ground level concentration along the plume centre-line in $\mathrm{mg} / \mathrm{m}^{3}$

\subsection{Emission Rates}

The Emission rates of pollutants released from the Diesel Engines were obtained by statistically averaging values of the pollutants' concentration measured at $1.0 \mathrm{~m}$ from the emission sources. This became imperative due to the difficulties that attend obtaining accurate value of emission rates for some point sources. The emission rates which are functions of source emission characteristics and geometry dominates the dispersion rate at points very close to the emission source(s). The average concentration of pollutants computed by Turner, (1970) for emission sources presented in equation (9) was applied at 1.0m receptor point to obtain the approximate emission rates for the criteria pollutants.

The dispersion parameters, $\sigma_{\mathrm{y} \text { and }} \sigma_{\mathrm{z}}$ were computed using the Brigg's interpolation equations for urban areas presented in table 2 . These parameters are dependent on downwind distances only.

\section{Results and Discussion}

The concentrations of gaseous pollutants released from 12 Horse power water-cooled Diesel Engines at specified receptor points were monitored and analyzed. The estimated emission rates of the gaseous pollutants are presented in table 3 . Tables $4 \mathrm{a}, 4 \mathrm{~b}$ and $4 \mathrm{c}$ present the average concentrations of Carbon (II) oxide monitored at specified receptor points downwind the diesel engines at the selected sites in Jos, Lafia and Makurdi respectively, while tables $5 \mathrm{a}, 5 \mathrm{~b}, 5 \mathrm{c}$ present the respective average concentrations of $\mathrm{SO}_{2}$. Hydrogen sulphide concentrations monitored at the Jos, Lafia and Makurdi sites are respectively presented in table $6 \mathrm{a}, 6 \mathrm{~b}$ and $6 \mathrm{c}$. Also presented in these tables are their respective descriptive statistics, which entail the range of concentrations, maximum and minimum concentrations, mean concentration, standard deviation and variance of the concentration and standard errors.

For deeper understanding of the trends of dispersion of these pollutants from these selected sites, figures were drawn to depict their average concentration at specific receptor points. These are presented in figures 3, 4 and 5 respectively for $\mathrm{CO}, \mathrm{SO}_{2}$ and $\mathrm{H}_{2} \mathrm{~S}$. These trends were further analysed using pie chart to show their percentage dispersion (or degree of transport of these pollutants) at every receptor points downwind the emission sources and presented in figures 6,7 and 8.

However, to evaluate the impacts of seasonal variations on the pollutants' concentration, tables 7 and 8 present the concentrations of pollutants during both dry and rainy seasons.

Since pollutants' concentration of emissions from diesel engines cannot be assessed everywhere they occur, it is needful to adopt modeling techniques in assessing pollutants' concentrations. Table 9 presents comparatively the modeled and measured concentrations of these criteria pollutants.

One vital factor that affects the magnitude of concentration of pollutant obtained at a specified receptor point downwind an emission source is the emission rate. Determination of the emission rate of any pollutant from a particular source is a major step in the simulation of the emission concentrations from that source in order to ascertain their environmental impact assessment. However, the emission rates are not uniform during the period of operation of the diesel engines; when operated under a load, they emit significant amounts of gaseous pollutants. Table 3 depicts Carbon (II) oxide, Sulphur (IV) oxide and Hydrogen sulphide emitted from $12 \mathrm{Hp}$ diesel engines as having respective estimated emission rates of $139.04 \mathrm{mg} / \mathrm{s}, 4.227 \mathrm{mg} / \mathrm{s}$ and $2.335 \mathrm{mg} / \mathrm{s}$. This shows that carbon (II) oxide has the highest emission rate among the pollutants investigated.

As pollutants are released from the $12 \mathrm{Hp}$ diesel engines in to the atmosphere, they are largely dispersed from these sources to various receptors points. The strength of this dispersion is evident in the decreasing magnitude of the concentrations of pollutants in the windward direction of the plume spread. The microenvironments around these emission sources experience the forceful impact of the momentum and buoyant release of pollutants before reasonable dispersion takes place. In this zone $(<1.0 \mathrm{~m}$ from the source), emission rate is prevalent over dispersion. However, as the pollutants are being transported farther downwind, dispersion process increases along the microenvironment, assuming the emission rate remains constant from the emission sources. The more the plume spread as a result of dispersion, the greater the volume of air available for dilution of pollutants. The dilution process is a function of the ability of the atmosphere (lower troposphere) to disperse 
the pollutants downwind the emission sources. This causes the average concentration of pollutants from the respective exhausts to follow exponentially decreases as depicted by figure 3, 4 and 5 .

12 Horse power water-cooled diesel engines (at least about $85 \%$ ) presently in use in North central Nigeria lack chimneys for lofting effluents from their exhausts as shown in figure 2. Hence their emissions are not lofted high in the atmosphere before dispersion takes place, thereby resulting in increase in ground level concentration of pollutants downwind within their microenvironments. These emissions are ejected horizontally with high exit velocities which encourages strong advection within the microenvironments of these sources while the chance of their vertical movement (or dilution) is dependent on the prevailing atmospheric stability conditions. Also, due to the momentous release that characterizes these sources, the forceful impacts of their emissions often defy the prevailing wind directions within the first few metres (1.0-3.0m) while the plumes succumb to the effects of wind direction thereafter. This explains the sharp decreases observed in pollutants concentration trends at point greater than $3.0 \mathrm{~m}$ as shown in tables $4-6$ and corroborated by figures 3-5.

To evaluate the strength of dispersion at various receptor points downwind the exhausts of these engines, figures 6-8 were obtained. A careful consideration of these figures show that at a distance of $5.0 \mathrm{~m}$ from the sources, about $95-99 \%$ of the pollutants would have dispersed, transporting only about $1-5 \%$ of the pollutants to the receptor points downwind. For CO specifically, about $51.0 \%$ of its concentration is obtained at $1.0 \mathrm{~m}$ from the different emission sources while about $1.0 \%$ eventually gets to the receptor point at $5.0 \mathrm{~m}$ downwind. For $\mathrm{SO}_{2}$ and $\mathrm{H}_{2} \mathrm{~S}$, about $50.0 \%$ of their concentrations are obtained at $1.0 \mathrm{~m}$ from these sources while about $4.0 \%$ eventually gets to the receptor point at $5.0 \mathrm{~m}$ downwind. These show that $\mathrm{CO}$ has higher dispersion than $\mathrm{SO}_{2}$ and $\mathrm{H}_{2} \mathrm{~S}$ among the pollutants investigated.

The standard deviations $(\sigma)$ of pollutants' concentrations from their mean concentrations are measures of the degree of dispersion that occurred. It is generally observed that the trends of variation of standard deviations of pollutants from the exhausts also decrease exponentially downwind as their corresponding mean concentrations and that these exponential decreases in standard deviation are higher for $\mathrm{CO}$ than that of $\mathrm{SO}_{2}$ and $\mathrm{H}_{2} \mathrm{~S}$ as presented in tables $4 \mathrm{a}-6 \mathrm{c}$. It is clear from these trends that the more the deviations, the lower the strength of dispersion. This is because dispersion from any source increases downwind while the standard deviations from the mean concentrations at the specific receptor points decrease downwind.

The set of atmospheric stability classes across North central Nigeria during the period of monitoring show a predominant occurrence of slightly unstable conditions and neutral conditions with few occurrences of moderately unstable and extremely unstable conditions. The stable condition had none occurrence. This is corroborated by literatures that temperature inversion that results in stable atmospheric conditions occurs more in the night. There were more occurrences of extremely unstable conditions and moderately unstable conditions during the rainy season than the drying season. For Jos city, of the total occurrences of extremely unstable atmospheric conditions, only about $32.4 \%$ occurred in dry season while about $67.4 \%$ occurred in the rainy season. The implication of predominant unstable atmospheric conditions is the enhancement of vertical mixing of the air which lead to highly variability in weather condition and dispersion of pollutants. However, to a good approximation, Lafia has the least extremely unstable conditions (about $3.11 \%$ ) but almost equal frequency occurrences of moderately unstable (about $44.9 \%$ ) and slightly unstable (about $44.0 \%$ ).

A comparative analysis of the monitored concentrations data sets monitored for all pollutants investigated during both dry and rainy seasons shown in tables 7 and 8 depict a remarkable contrast; the rainy season' values are generally lower than the dry season values for exhausts of the selected diesel engines. This is solely attributed to the fact that atmospheric instability conditions are more prevalent during rainy seasons than the dry seasons. For unstable atmosphere, the vertical mixing of pollutants resulting in high dispersion rates is enhanced. This causes dilution of the pollutants in the atmosphere even as they are advecting downwind these sources resulting in lower concentrations. However, under less unstable atmosphere, the vertical mixing of pollutants is not much thereby leading to higher concentrations downwind. This atmospheric condition is more in dry season than in rainy season; hence a higher concentration levels for dry seasons as shown in tables 7 and 8 .

Furthermore, the topography of Jos should naturally enhance dispersion of pollutants than that of Lafia and Makurdi; this is due its location at a high elevation (see table 1) and the prevalent occurrences of higher wind speeds. This is clearly depicted by figures 3, 4 and 5. These figures show Jos sites as having the steepest trends for concentration variation level for all pollutants monitored. This could be attributed to the high dispersion of these emissions from the exhausts to specified receptor points. However, the concentrations of pollutants downwind any source is subject to interplay of many factors such as their emission rates, atmospheric stability conditions and the combustion conditions of the individual engines. It was observed during monitoring that although Jos sites have the Diesel Engine with the worst combustion conditions which result in emissions that are highly deleterious to the environment, its atmosphere has the greatest dilution ability as a result of the city's elevation and high wind speed. 
Comparatively, it could be observed from table 9 that the measured concentration of the pollutants investigated is higher than the modeled data at receptor points greater than $1.0 \mathrm{~m}$. This may be due to the occurrence of very complex and unpredictable atmospheric dynamics which may be as a result of wind shearing and turbulence which was not accounted for by the modeling equation. However, this research has given measure of validation to Gaussian Plume Model for application to ground emission sources for the criteria pollutants investigated. Analysing the regression coefficients of the measured and modeled concentrations using scattered plot as shown in figures $9 \mathrm{a}, 9 \mathrm{~b}$ and $9 \mathrm{c}$ for diesel engine emissions reveals a high degree of correlation between modeled and measured data for $\mathrm{CO}, \mathrm{SO}_{2}$ and $\mathrm{H}_{2} \mathrm{~S}$. The respective coefficient of regression, $\mathrm{R}^{2}$ for $\mathrm{CO}, \mathrm{SO}_{2}$ and $\mathrm{H}_{2} \mathrm{~S}$ for measured and modeled concentration from these sources are 0.874, 0.960 and 0.968 . These depict measured and modeled $\mathrm{CO}, \mathrm{SO}_{2}$ and $\mathrm{H}_{2} \mathrm{~S}$ concentrations correlating highly. These express a high validation of Gaussian plume model for use in predicting the ground level centerline concentration of $\mathrm{CO}, \mathrm{SO}_{2}$ and $\mathrm{H}_{2} \mathrm{~S}$ emitted from Diesel Engine. It can therefore be safely concluded that Gaussian Plume Model can be used to capture the real-time features of the dispersal of these selected pollutants from these sources.

\section{Conclusion}

Based on National Ambient Air Quality Standards, the immediate microenvironments of these sources are unsafe for $\mathrm{CO}\left(1\right.$-hour time average, the safe limit is $\left.40 \mathrm{mgm}^{-3}\right)$ at downwind distances less than $3.0 \mathrm{~m}$ and for $\mathrm{SO}_{2}$ (1-hour time average, the safe limit is $0.196 \mathrm{mgm}^{-3}$ ) at downwind distances less than $4.0 \mathrm{~m}$. However, for $\mathrm{H}_{2} \mathrm{~S}$, there is no National Ambient Air Quality Standards but evaluating its levels with the National Ambient California (i.e 1-hour time average, the safe limit is $0.042 \mathrm{mg} / \mathrm{m}^{3}$ ), it can be concluded that these sources are unsafe for $\mathrm{H}_{2} \mathrm{~S}$ within the microenvironments of $5.0 \mathrm{~m}$.

From the trend of pollutants' variation, it is obvious that it occurs virtually continuously within the microenvironments of the selected sites. Analysing these trends seasonally depict the rainy seasons as having lower concentration levels of these pollutants investigated than that of the dry season. This is due to higher occurrences of atmospheric instability during the rainy season.

\section{Recommendations}

Since the emissions within the microenvironments of the selected sites of Diesel Engines are potentially hazardous to both human and public health, it is therefore recommended that Environmental Regulatory Agencies enact policies that make chimney attachment a precondition for granting licenses for any $12 \mathrm{Hp}$ Diesel engine to operate in North central Nigeria.

It is also recommended that exposure to these sources be grossly reduced by the enactment of policies by relevant environmental agencies that regulate the duration of exposure to these sources so as to reduce the health impact of these emissions, most especially for people working directly within these microenvironments.

Furthermore, since these pollutants are generated in combustion, modifications to the combustion process itself by ensuring greater air to fuel mixture in the combustion chamber design can be quite effective in reducing their formation.

Table 1: Selected Monitored Diesel Engine Sites across North Central Nigeria

\begin{tabular}{|c|c|c|c|c|}
\hline $\mathrm{S} / \mathrm{N}$ & SITES & LOCATIONS & COORDINATES & ELEVATIONS \\
\hline 1 & 12 Hp DIESEL Engine, Makurdi. & $\begin{array}{l}\text { Before River Benue Bridge, } \\
\text { Makurdi. Benue State. }\end{array}$ & $\begin{array}{l}\text { N07 } 44^{\prime} 38.0^{\prime \prime} \\
\text { E008 } 33^{\prime} 08.5^{\prime \prime}\end{array}$ & $82.00 \mathrm{~m}$ \\
\hline 2 & $\begin{array}{l}12 \text { Hp Diesel Engine, Before } \\
\text { College, Lafia }\end{array}$ & $\begin{array}{l}\text { Before College of } \\
\text { Agriculture, Lafia, Nasarawa. }\end{array}$ & $\begin{array}{l}\text { N08 32'45.9”' } \\
\text { E008 } 32^{\prime} 06.0^{\prime \prime}\end{array}$ & $186.00 \mathrm{~m}$ \\
\hline 3 & $12 \mathrm{hp}$ Diesel Engine, Jos & Army Engineers, Jos & $\begin{array}{l}\text { N09 } 58^{\prime} 11.9^{\prime \prime} \\
\text { E } 008^{0} 50 \text { '50.4", }\end{array}$ & $1148.0 \mathrm{~m}$ \\
\hline
\end{tabular}

Table 2-Briggs Interpolation Formula For Urban Areas

\begin{tabular}{|l|l|l|}
\hline Pasquil Type & $\sigma_{\mathrm{y}(\mathrm{m})}$ & $\sigma_{\mathrm{z}(\mathrm{m})}$ \\
\hline A-B & $0.32 \mathrm{X}(1+0.0004 \mathrm{X})^{-1 / 2}$ & $0.24 \mathrm{X}(1+0.001 \mathrm{X})^{1 / 2}$ \\
\hline C & $0.22 \mathrm{X}(1+0.0004 \mathrm{X})^{-1 / 2}$ & $0.20 \mathrm{X}$ \\
\hline D & $0.16 \mathrm{X}(1+0.0004 \mathrm{X})^{-1 / 2}$ & $0.14 \mathrm{X}(1+0.0003 \mathrm{X})^{-1 / 2}$ \\
\hline E-F & $0.11(1+0.0004 \mathrm{X})^{-1 / 2}$ & $0.08 \mathrm{X}(1+0.0015 \mathrm{X})^{-1}$ \\
\hline
\end{tabular}

Source: Briggs, G.A., (1972)

Table 3: Estimated Emission Rates (in mg/s) of Gaseous pollutants from 12 Horse Power Diesel Engines.

\begin{tabular}{|l|c|l|l|l|}
\hline SOURCES & $\begin{array}{l}\text { WIND SPEED AT POINT } \\
\text { OF ADVECTION }(\mathrm{m} / \mathrm{s})\end{array}$ & $\begin{array}{l}\mathrm{CO} \\
(\mathrm{mg} / \mathrm{s})\end{array}$ & $\mathrm{SO}_{2}$ & $\mathrm{H}_{2} \mathrm{~S}$ \\
\hline 12 Horse Power Diesel engine & 7.93 & 139.04 & 4.227 & 2.335 \\
\hline
\end{tabular}


Dispersion and Modeling of Gaseous Pollutants Released From 12 Hp Diesel Engines at Some ..

Table 4a: Carbon (II) oxide Concentration (in $\mathrm{mg} / \mathrm{m}^{3}$ ) emitted from $12 \mathrm{Hp}$ Diesel Engine in Lafia, Plateau State-Nigeria

\begin{tabular}{|l|l|l|l|l|l|l|l|l|l|l|}
\hline & N & RG & Min. & Max. & Mean & Std. Dev. & \multicolumn{1}{l|}{ Var. } & \multicolumn{2}{l|}{ Skewness } \\
\hline $\mathrm{X}(\mathrm{m})$ & Statistic & Statistic & Statistic & Statistic & Statistic & Std. Error & Statistic & Statistic & Statistic & Std. Error \\
\hline 1.0 & 45 & 613.31 & 16.4 & 629.71 & 85.76 & 14.8 & 99.37 & 9874.0 & 4.167 & 0.354 \\
\hline 2.0 & 45 & 164.09 & 11.9 & 176.00 & 38.54 & 4.76 & 31.93 & 1019.0 & 3.103 & 0.354 \\
\hline 3.0 & 45 & 135.25 & 1.00 & 136.25 & 17.85 & 3.08 & 20.63 & 425.76 & 4.452 & 0.354 \\
\hline 4.0 & 44 & 44.08 & 0.00 & 44.08 & 7.40 & 1.28 & 8.50 & 72.31 & 2.086 & 0.357 \\
\hline 5.0 & 45 & 23.28 & 0.00 & 23.28 & 2.92 & 0.78 & 5.23 & 27.32 & 2.310 & 0.354 \\
\hline
\end{tabular}

Table 4b: Carbon (II) oxide Concentration (in $\mathrm{mg} / \mathrm{m}^{3}$ ) emitted from $12 \mathrm{Hp}$ Diesel Engine in Lafia, Nasarawa

\begin{tabular}{|l|l|l|l|l|l|l|l|l|l|l|}
\hline $\mathrm{X}(\mathrm{m})$ & N & RG & Min. & Max. & Mean & Std. Dev. & Var. & Skewness & & \\
\hline & Statistic & Statistic & Statistic & Statistic & Statistic & Std. Error & Statisti & Statistic & Statistic & Std. Error \\
\hline 1.0 & 12 & 184.15 & 26.17 & 210.32 & 75.16 & 15.85 & 54.90 & 3013.00 & 1.71 & 0.637 \\
\hline 2.0 & 12 & 204.88 & 17.56 & 222.44 & 58.74 & 20.60 & 71.34 & 5090.00 & 2.01 & 0.637 \\
\hline 3.0 & 12 & 31.48 & 1.72 & 33.20 & 14.96 & 2.71 & 9.39 & 88.18 & 0.63 & 0.637 \\
\hline 4.0 & 12 & 7.45 & 1.14 & 8.59 & 3.58 & 0.70 & 2.41 & 5.82 & 1.10 & 0.637 \\
\hline 5.0 & 12 & 5.15 & 0.00 & 5.15 & 1.00 & 0.41 & 1.41 & 1.98 & 2.65 & 0.637 \\
\hline
\end{tabular}

Table 4c: Carbon (II) oxide Concentrations (in $\mathrm{mg} / \mathrm{m}^{3}$ ) emitted from $12 \mathrm{Hp}$ Diesel Engine in Makurdi, Benue State-Nigeria

\begin{tabular}{|l|l|l|l|l|l|l|l|l|l|l|}
\hline & $\mathrm{N}$ & RG & Min. & Max. & Mean & Std. Dev. & \multicolumn{2}{l|}{ Var. } & \multicolumn{2}{l|}{ Skewness } \\
\hline $\mathrm{X}(\mathrm{m})$ & & Statistic & Statistic & Statistic & Statistic & Std. Error & Statistic & Statistic & Statistic & Std. Error \\
\hline 1.0 & 15 & 57.24 & 32.06 & 89.30 & 48.27 & 4.50 & 17.42 & 303.333 & 1.723 & 0.580 \\
\hline 2.0 & 15 & 44.28 & 5.72 & 50.00 & 24.80 & 3.61 & 13.98 & 195.391 & 0.487 & 0.580 \\
\hline 3.0 & 15 & 27.62 & 1.00 & 28.62 & 9.29 & 2.32 & 9.00 & 81.005 & 1.008 & 0.580 \\
\hline 4.0 & 16 & 13.00 & 0.00 & 13.00 & 2.16 & 0.76 & 3.06 & 9.340 & 3.343 & 0.564 \\
\hline 5.0 & 13 & 9.33 & 0.00 & 9.33 & 1.20 & 0.70 & 2.51 & 6.318 & 3.264 & 0.616 \\
\hline
\end{tabular}

Table 5a: Sulphur (IV) oxide Concentration (in $\mathrm{mg} / \mathrm{m}^{3}$ ) emitted from $12 \mathrm{Hp}$ Diesel

Engine in Jos, Plateau State-Nigeria

\begin{tabular}{|l|l|l|l|l|l|l|l|l|l|l|}
\hline $\mathrm{X}(\mathrm{m})$ & $\mathrm{N}$ & RG & Min. & Max. & Mean & Std. Dev. & \multicolumn{2}{l|}{ Var. } & \multicolumn{2}{l|}{ Skewness } \\
\hline & Statistic & Statistic & Statistic & Statistic & Statistic & Std. Error & Statistic & Statistic & Statistic & Std. Error \\
\hline 1.0 & 45 & 26.19 & 0.00 & 26.19 & 2.95 & 0.62 & 4.17 & 17.36 & 4.23 & 0.35 \\
\hline 2.0 & 45 & 4.71 & 0.00 & 4.71 & 1.00 & 0.14 & 0.92 & 0.85 & 2.41 & 0.35 \\
\hline 3.0 & 45 & 2.76 & 0.13 & 2.89 & 0.55 & 0.08 & 0.52 & 0.27 & 2.89 & 0.35 \\
\hline 4.0 & 45 & 1.18 & 0.00 & 1.18 & 0.33 & 0.04 & 0.26 & 0.07 & 1.52 & 0.35 \\
\hline 5.0 & 45 & .79 & 0.00 & 0.79 & 0.17 & 0.03 & 0.17 & 0.03 & 1.49 & 0.35 \\
\hline
\end{tabular}

Table 5b: Sulphur (IV) oxide Concentrations (in mg/m³ ${ }^{3}$ Level from 12 Hp Diesel Engine in Lafia, Nasarawa State-Nigeria

\begin{tabular}{|l|l|l|l|l|l|l|l|l|l|l|}
\hline & $\mathrm{N}$ & RG & Min. & Max & Mean & Std. Dev. & Var. & \multicolumn{2}{l|}{ Skewness } \\
\hline $\mathrm{X}(\mathrm{m})$ & & Statistic & Statistic & Statistic & Statistic & Std. Error & Statistic & Statistic & Statistic & Std. Error \\
\hline 1.0 & 16 & 4.28 & 0.26 & 4.54 & 1.45 & 0.33 & 1.34 & 1.784 & 1.222 & 0.564 \\
\hline 2.0 & 16 & 3.41 & 0.13 & 3.54 & 0.85 & 0.22 & 0.87 & 0.755 & 2.272 & 0.564 \\
\hline 3.0 & 16 & 1.57 & 0.13 & 1.70 & 0.51 & 0.11 & 0.44 & 0.191 & 1.542 & 0.564 \\
\hline 4.0 & 16 & 2.22 & 0.07 & 2.29 & 0.43 & 0.15 & 0.60 & 0.354 & 2.605 & 0.564 \\
\hline 5.0 & 13 & 0.92 & 0.00 & 0.92 & 0.17 & 0.07 & 0.25 & 0.061 & 2.666 & 0.616 \\
\hline
\end{tabular}

Table 5c: Sulphur (IV) oxide Concentration (in $\mathrm{mg} / \mathrm{m}^{3}$ ) emitted from $12 \mathrm{Hp}$ Diesel Engine in Makurdi, Benue State-Nigeria

\begin{tabular}{|l|l|l|l|l|l|l|l|l|l|l|}
\hline & $\mathrm{N}$ & RG. & Min. & Max. & Mean & Std. Dev. & \multicolumn{2}{l|}{ Var. } & \multicolumn{2}{l|}{ Skewness } \\
\hline $\mathrm{X}(\mathrm{m})$ & & Statistic & Statistic & Statistic & Statistic & Std. Error & Statistic & Statistic & Statistic & Std. Error \\
\hline 1.0 & 15 & 3.54 & 0.39 & 3.93 & 1.34 & 0.26 & 1.00 & 1.003 & 1.550 & 0.580 \\
\hline 2.0 & 15 & 2.44 & 0.26 & 2.70 & 0.86 & 0.18 & 0.70 & 0.486 & 1.607 & 0.580 \\
\hline 3.0 & 15 & 0.66 & 0.13 & 0.79 & 0.36 & 0.06 & 0.21 & 0.045 & 0.607 & 0.580 \\
\hline 4.0 & 14 & 0.65 & 0.00 & 0.65 & 0.24 & 0.05 & 0.18 & 0.034 & 0.873 & 0.597 \\
\hline 5.0 & 13 & 0.39 & 0.00 & 0.39 & 0.17 & 0.03 & 0.11 & 0.012 & 0.528 & 0.616 \\
\hline
\end{tabular}


Dispersion and Modeling of Gaseous Pollutants Released From 12 Hp Diesel Engines at Some ..

Table 6a: Hydrogen sulphide Concentration (in $\mathrm{mg} / \mathrm{m}^{3}$ ) emitted from $12 \mathrm{Hp}$ Diesel

Engine in Jos, Plateau State-Nigeria

\begin{tabular}{|l|l|l|l|l|l|l|l|l|l|l|}
\hline & N & Range & Min. & Max. & Mean & Std. Dev. & Var. & \multicolumn{2}{l|}{ Skewness } \\
\hline $\mathrm{X}(\mathrm{m})$ & Statistic & Statistic & Statistic & Statistic & Statistic & Std. Error & Statistic & Statistic & Statistic & Std. Error \\
\hline $1.0 \mathrm{~m}$ & 45 & 22.29 & 0.0 & 22.29 & 1.68 & 0.53 & 3.58 & 12.78 & 4.70 & .354 \\
\hline $2.0 \mathrm{~m}$ & 45 & 2.79 & 0.0 & 2.79 & 0.65 & 0.12 & 0.82 & 0.67 & 1.29 & .354 \\
\hline $3.0 \mathrm{~m}$ & 45 & 2.09 & 0.0 & 2.09 & 0.31 & 0.09 & 0.60 & 0.37 & 1.77 & .354 \\
\hline $4.0 \mathrm{~m}$ & 44 & 1.39 & 0.0 & 1.39 & 0.28 & 0.08 & 0.53 & 0.28 & 1.48 & .357 \\
\hline $5.0 \mathrm{~m}$ & 45 & 1.39 & 0.0 & 1.39 & 0.21 & 0.07 & 0.44 & 0.20 & 1.95 & .354 \\
\hline
\end{tabular}

Table 6b: Hydrogen sulphide Concentration (in $\mathrm{mg} / \mathrm{m}^{3}$ ) emitted from $12 \mathrm{Hp}$ Diesel Engine in Lafia, Nasarawa State-Nigeria

\begin{tabular}{|l|l|l|l|l|l|l|l|l|l|l|}
\hline & $\mathrm{N}$ & Range & Min. & Max. & Mean & Std. Dev. & Var. & \multicolumn{2}{l|}{ Skewness } \\
\hline $\mathrm{X}(\mathrm{m})$ & & Statistic & Statistic & Statistic & Statistic & Std. Error & Statistic & Statistic & Statistic & Std. Error \\
\hline 1.0 & 16 & 2.09 & 0.00 & 2.09 & 0.69 & 0.24 & 0.95 & 0.90 & 0.716 & 0.564 \\
\hline 2.0 & 16 & 1.39 & 0.00 & 1.39 & 0.39 & 0.16 & 0.62 & 0.39 & 1.072 & 0.564 \\
\hline 3.0 & 16 & 1.39 & 0.00 & 1.39 & 0.35 & 0.13 & 0.51 & 0.26 & 1.163 & 0.564 \\
\hline 4.0 & 15 & 1.39 & 0.00 & 1.39 & 0.28 & 0.13 & 0.51 & 0.26 & 1.639 & 0.580 \\
\hline 5.0 & 14 & 0.00 & 0.00 & 0.00 & 0.00 & 0.00 & 0.00 & 0.00 &. &. \\
\hline
\end{tabular}

Table 6c: Hydrogen sulphide Concentration (in $\mathrm{mg} / \mathrm{m}^{3}$ ) emitted from $12 \mathrm{Hp}$ Diesel Engine in Makurdi, Benue State-Nigeria

\begin{tabular}{|l|l|l|l|l|l|l|l|l|l|l|}
\hline & $\mathrm{N}$ & RG & Min. & Max. & Mean & Std. Dev. & \multicolumn{2}{l|}{ Var. } & \multicolumn{2}{l|}{ Skewness } \\
\hline $\mathrm{X}(\mathrm{m})$ & & Statistic & Statistic & Statistic & Statistic & Std. Error & Statistic & Statistic & Statistic & Std. Error \\
\hline 1.0 & 15 & 2.09 & 0.00 & 2.09 & 0.60 & 0.20 & 0.78 & 0.613 & 0.646 & 0.580 \\
\hline 2.0 & 15 & 1.39 & 0.00 & 1.39 & 0.28 & 0.13 & 0.51 & 0.263 & 1.625 & 0.580 \\
\hline 3.0 & 15 & 1.39 & 0.00 & 1.39 & 0.14 & 0.10 & 0.39 & 0.152 & 2.911 & 0.580 \\
\hline 4.0 & 14 & 1.39 & 0.00 & 1.39 & 0.10 & 0.10 & 0.37 & 0.138 & 3.742 & 0.597 \\
\hline 5.0 & 13 & 0.65 & 0.00 & 0.65 & 0.05 & 0.05 & 0.18 & 0.032 & 3.606 & 0.616 \\
\hline
\end{tabular}

Table 7: Monitored Concentration levels $\left(\mathrm{mg} / \mathrm{m}^{3}\right)$ of Gaseous Pollutants North Central Nigeria during the Dry Season

\begin{tabular}{|c|c|c|c|c|c|c|c|c|c|c|c|c|c|c|c|c|c|}
\hline \multirow[t]{2}{*}{$\mathrm{X}(\mathrm{m})$} & \multirow[b]{2}{*}{ CO(JOS) } & \multirow[b]{2}{*}{$\sigma$} & & \multirow[b]{2}{*}{$\begin{array}{l}\mathrm{H}_{2} \mathrm{~S} \\
\text { (JOS) }\end{array}$} & \multirow[b]{2}{*}{$\sigma$} & & \multirow[b]{2}{*}{$\begin{array}{l}\mathrm{SO}_{2} \\
\text { (LF) }\end{array}$} & \multirow[b]{2}{*}{$\sigma$} & \multirow[b]{2}{*}{$\mathrm{H}_{2} \mathrm{~S}(\mathrm{LF})$} & \multirow[b]{2}{*}{$\sigma$} & \multirow[b]{2}{*}{$\begin{array}{l}\mathrm{CO} \\
(\mathrm{MK})\end{array}$} & \multirow[b]{2}{*}{$\begin{array}{l}\mathrm{SO}_{2} \\
(\mathrm{MK})\end{array}$} & \multirow[b]{2}{*}{$\sigma$} & \multirow[b]{2}{*}{$\begin{array}{l}\mathrm{H}_{2} \mathrm{~S} \\
(\mathrm{MK})\end{array}$} & \multirow[b]{2}{*}{$\sigma$} \\
\hline & & & $\begin{array}{l}\mathrm{SO} 2 \\
\text { (JOS) }\end{array}$ & & & & $\begin{array}{l}\mathrm{CO} \\
\text { (LF) }\end{array}$ & $\sigma$ & & & & & & & & & \\
\hline 1.00 & 107.50 & 128.65 & 3.93 & 5.29 & 2.39 & 4.66 & 67.59 & 49.48 & 1.45 & 1.34 & 0.69 & 0.95 & 89.30 & 17.42 & 1.00 & 0.60 & 0.78 \\
\hline 2.00 & 44.43 & 40.81 & 1.16 & 1.13 & 0.81 & 1.00 & 51.83 & 62.53 & 0.85 & 0.87 & 0.39 & 0.62 & 50.00 & 14.00 & 0.70 & 0.28 & 0.51 \\
\hline 3.00 & 19.08 & 26.31 & 0.58 & 0.58 & 0.45 & 0.72 & 14.05 & 9.00 & 0.51 & 0.44 & 0.35 & 0.51 & 28.62 & 9.00 & 0.21 & 0.14 & 0.39 \\
\hline 4.00 & 8.95 & 10.06 & 0.36 & 0.29 & 0.40 & 0.59 & 3.22 & 2.21 & 0.43 & 0.60 & 0.28 & 0.51 & 13.00 & 3.25 & 0.18 & 0.10 & 0.37 \\
\hline 5.00 & 3.52 & 5.95 & 0.16 & 0.18 & 0.24 & 0.45 & 0.95 & 1.28 & 0.17 & 0.25 & 0.00 & 0.00 & 9.33 & 2.51 & 0.11 & 0.05 & 0.18 \\
\hline
\end{tabular}

Note: LF: Lafia ; MK: Makurdi; ${ }^{\sigma}=$ standard deviation

Table 8: Monitored Concentration levels of Gaseous Pollutants North Central Nigeria during the Rainy Season

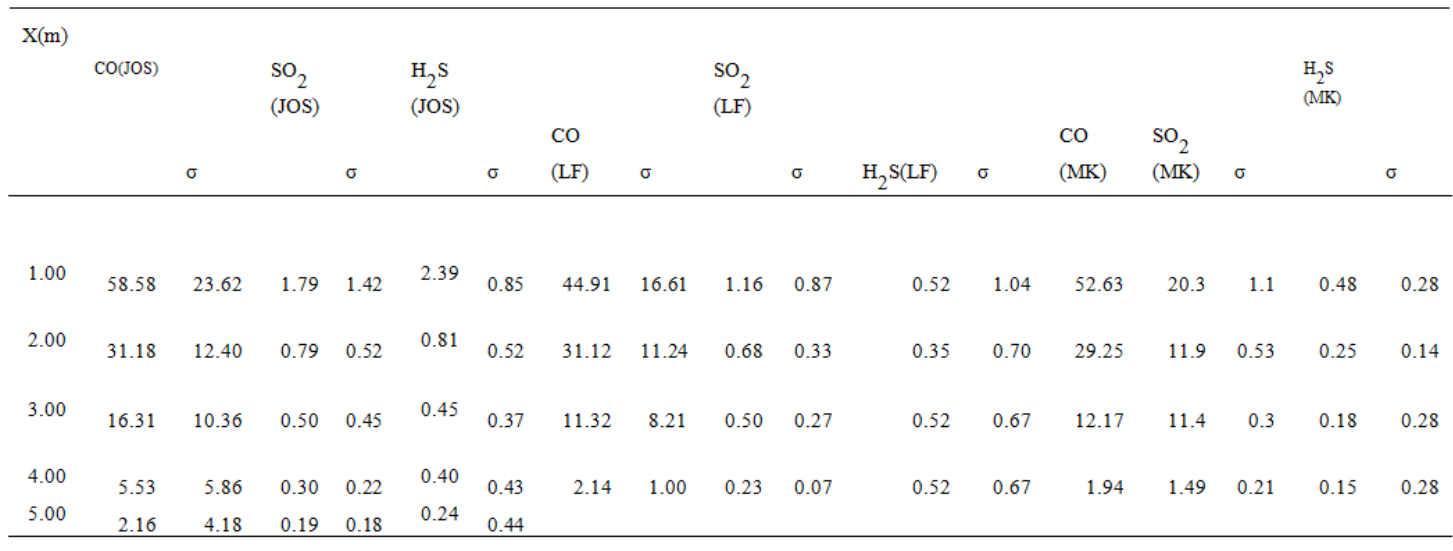


Dispersion and Modeling of Gaseous Pollutants Released From 12 Hp Diesel Engines at Some ..

Table 9: Average Measured and Modeled Concentration (in $\mathrm{mg} / \mathrm{m}^{3}$ ) of Gaseous Pollutants Emitted from $12 \mathrm{Hp}$

\begin{tabular}{|l|l|l|l|l|l|l|}
\hline $\mathrm{X}(\mathrm{m})$ & $\begin{array}{l}\mathrm{CO} \\
(\mathrm{MSD})\end{array}$ & $\begin{array}{l}\mathrm{CO} \\
(\mathrm{MDL})\end{array}$ & $\begin{array}{l}\mathrm{SO}_{2} \\
(\mathrm{MSD})\end{array}$ & $\begin{array}{l}\mathrm{SO}_{2} \\
(\mathrm{MSD})\end{array}$ & $\begin{array}{l}\mathrm{H}_{2} \mathrm{~S} \\
(\mathrm{MSD})\end{array}$ & $\begin{array}{l}\mathrm{H}_{2} \mathrm{~S} \\
(\mathrm{MDL})\end{array}$ \\
\hline 1.0 & 69.50 & 87.21 & 1.91 & 2.65 & 0.99 & 1.47 \\
\hline 2.0 & 40.70 & 21.80 & 0.90 & 0.66 & 0.44 & 0.37 \\
\hline 3.0 & 14.03 & 9.69 & 0.47 & 0.29 & 0.27 & 0.16 \\
\hline 4.0 & 4.38 & 5.45 & 0.33 & 0.17 & 0.22 & 0.09 \\
\hline 5.0 & 1.71 & 3.49 & 0.17 & 0.11 & 0.09 & 0.06 \\
\hline
\end{tabular}

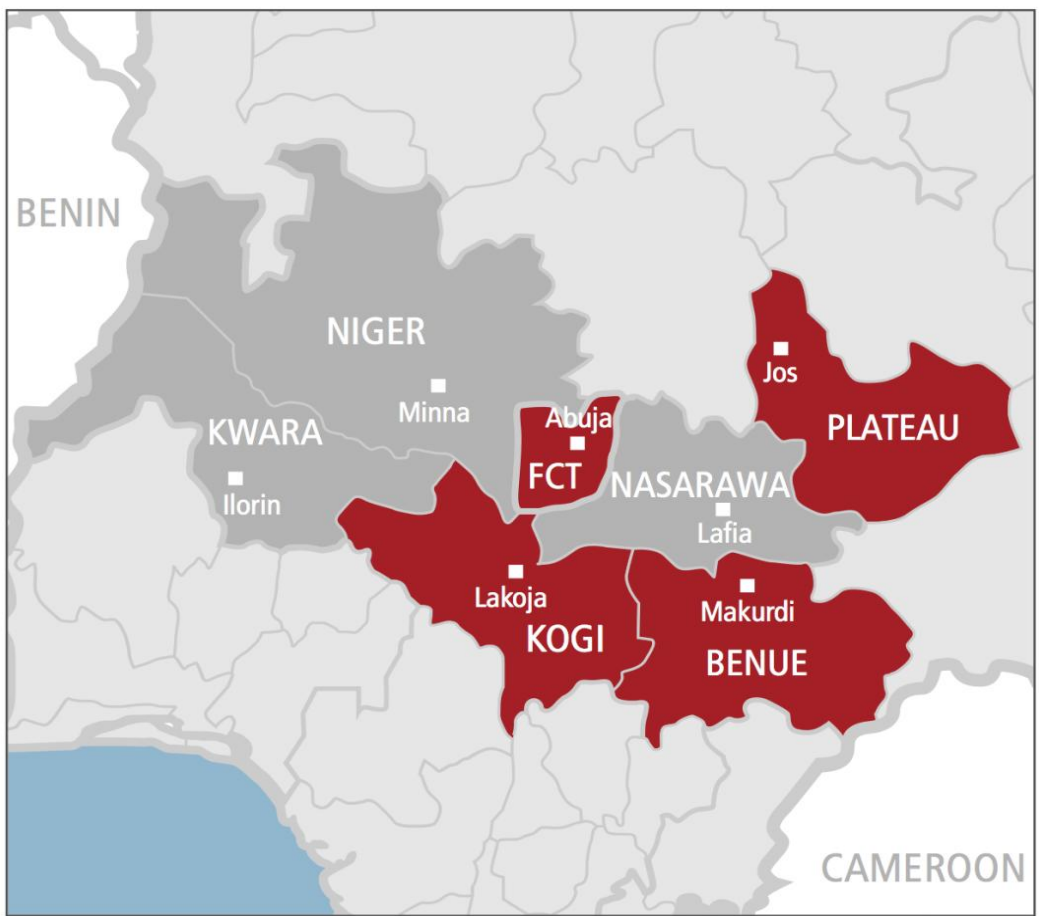

Fig. 1: Map of North central Nigeria

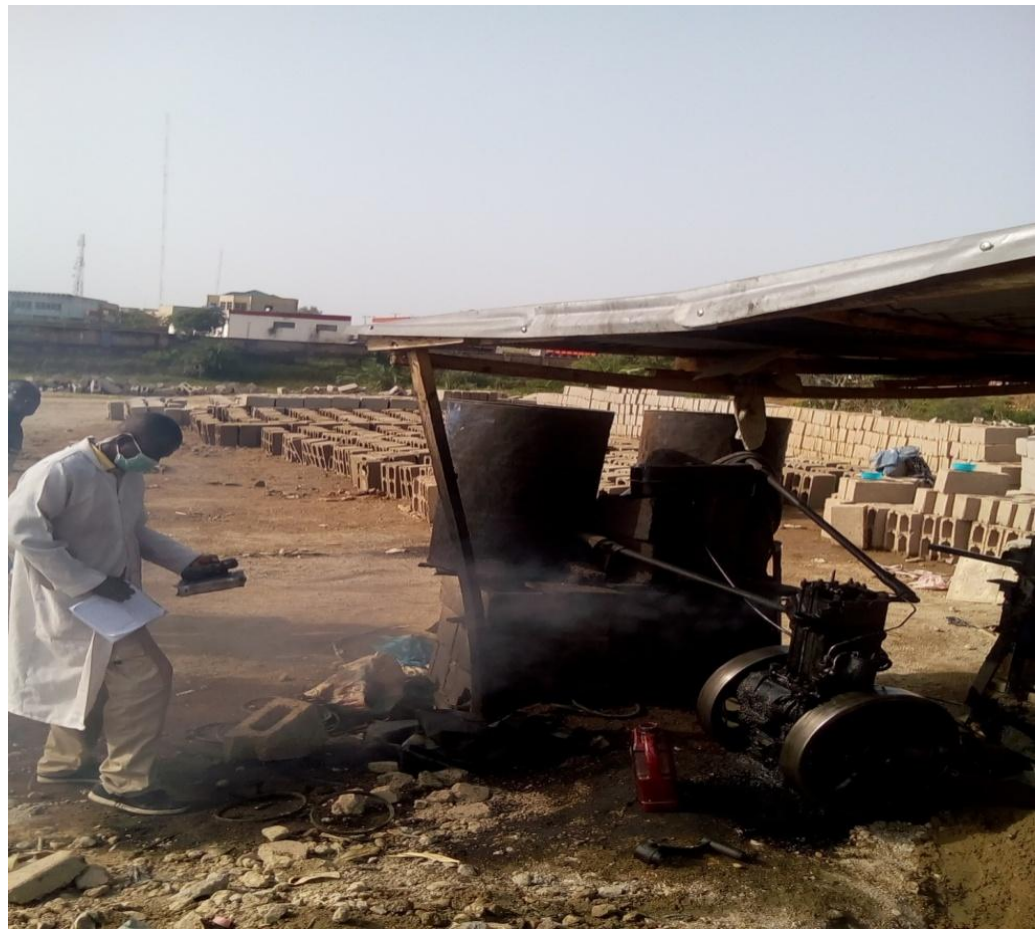

Fig. 2: $12 \mathrm{Hp}$ water-cooled Diesel Engine during Monitoring 


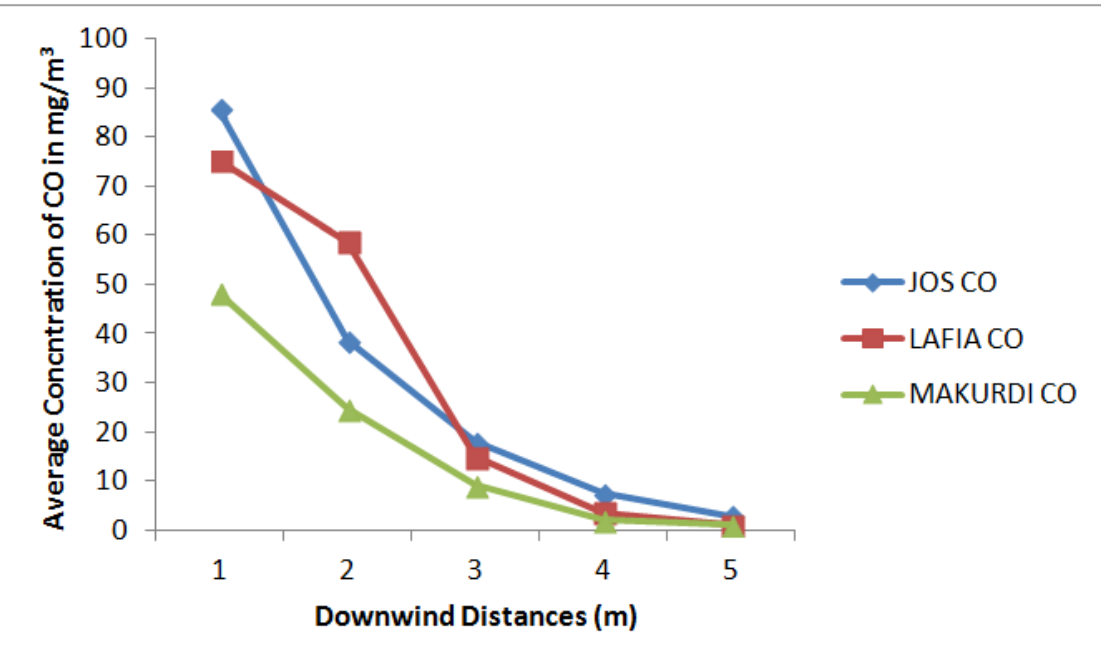

Fig. 3: Average Concentration of $\mathrm{CO}$ at various Receptor points from $12 \mathrm{Hp}$ Diesel Engine

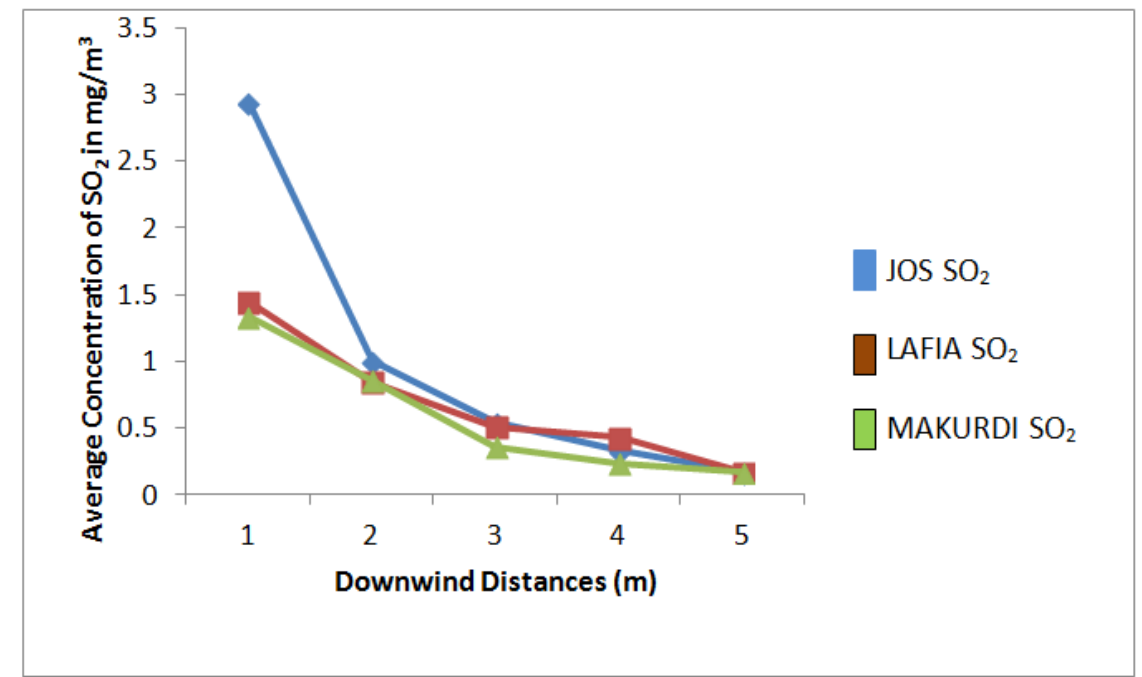

Fig. 4: Average Concentration of $\mathrm{SO}_{2}$ at various Receptor points from $12 \mathrm{Hp}$ Diesel Engines

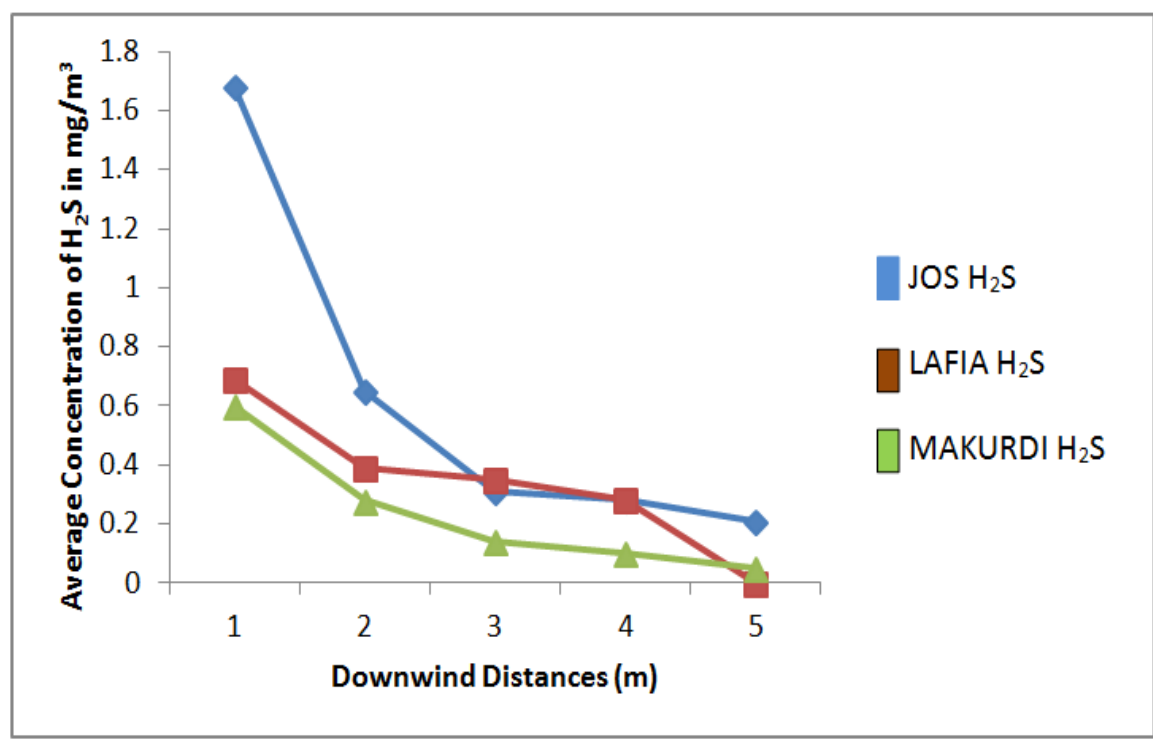

Fig.5: Average Concentration of $\mathrm{H}_{2} \mathrm{~S}$ at various Receptor points from $12 \mathrm{Hp}$ Diesel Engine 


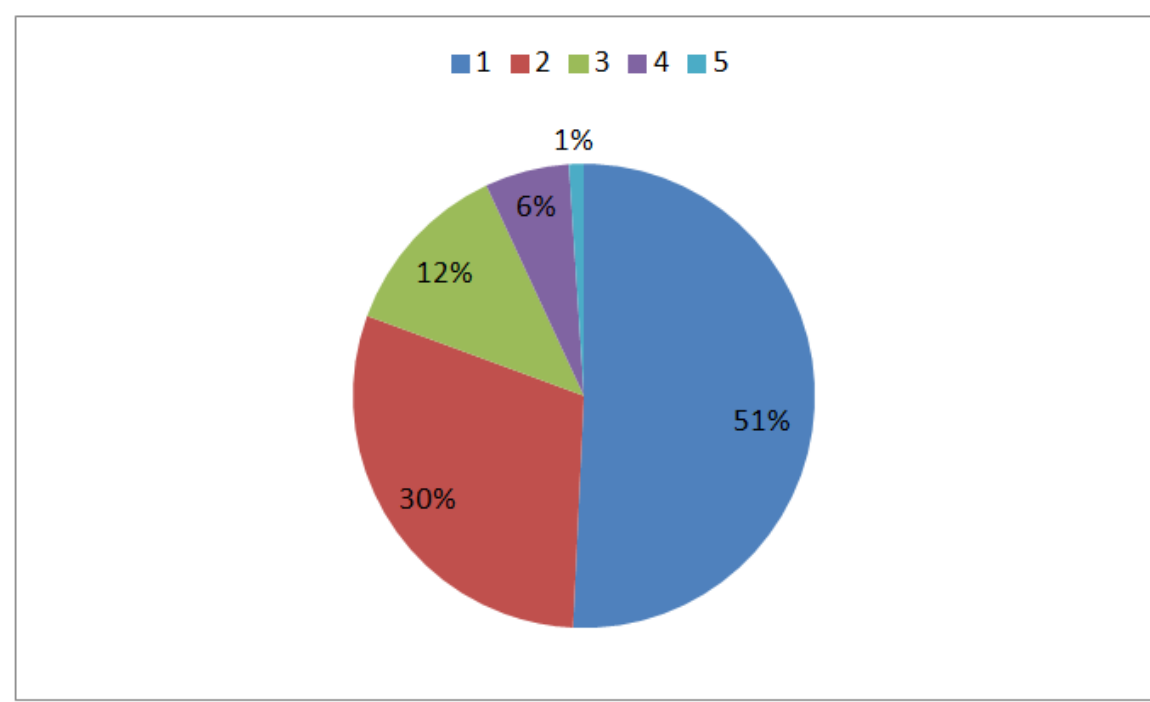

Fig. 6: Percentage Dispersion trend of CO from Selected Sites

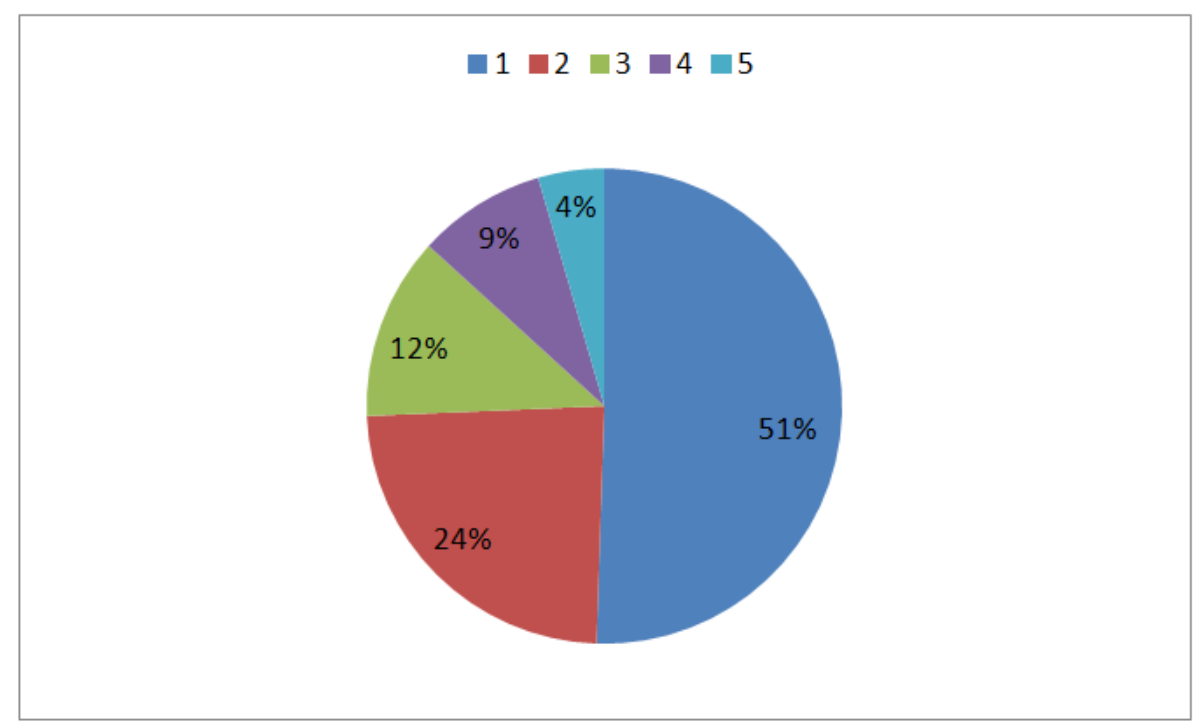

Fig. 7: Percentage Dispersion trend of $\mathrm{SO}_{2}$ from Selected Sites

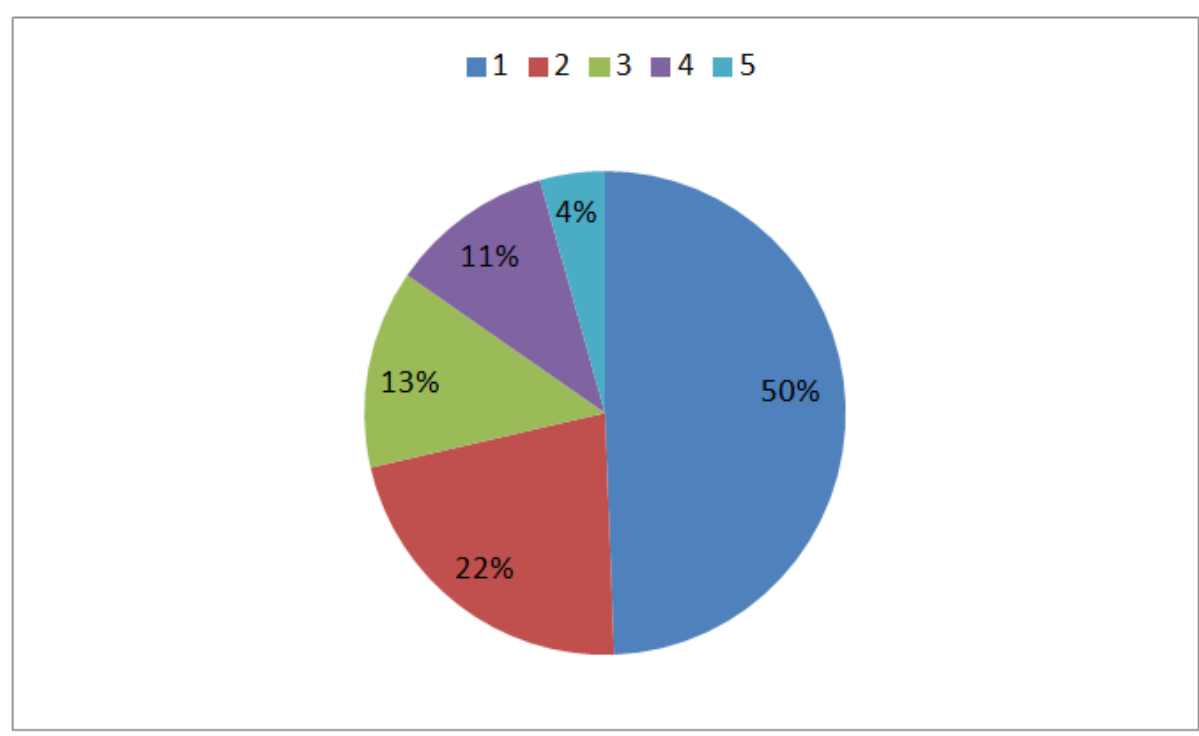

Fig. 8: Percentage Dispersion trend of $\mathrm{H}_{2} \mathrm{~S}$ from Selected Sites 


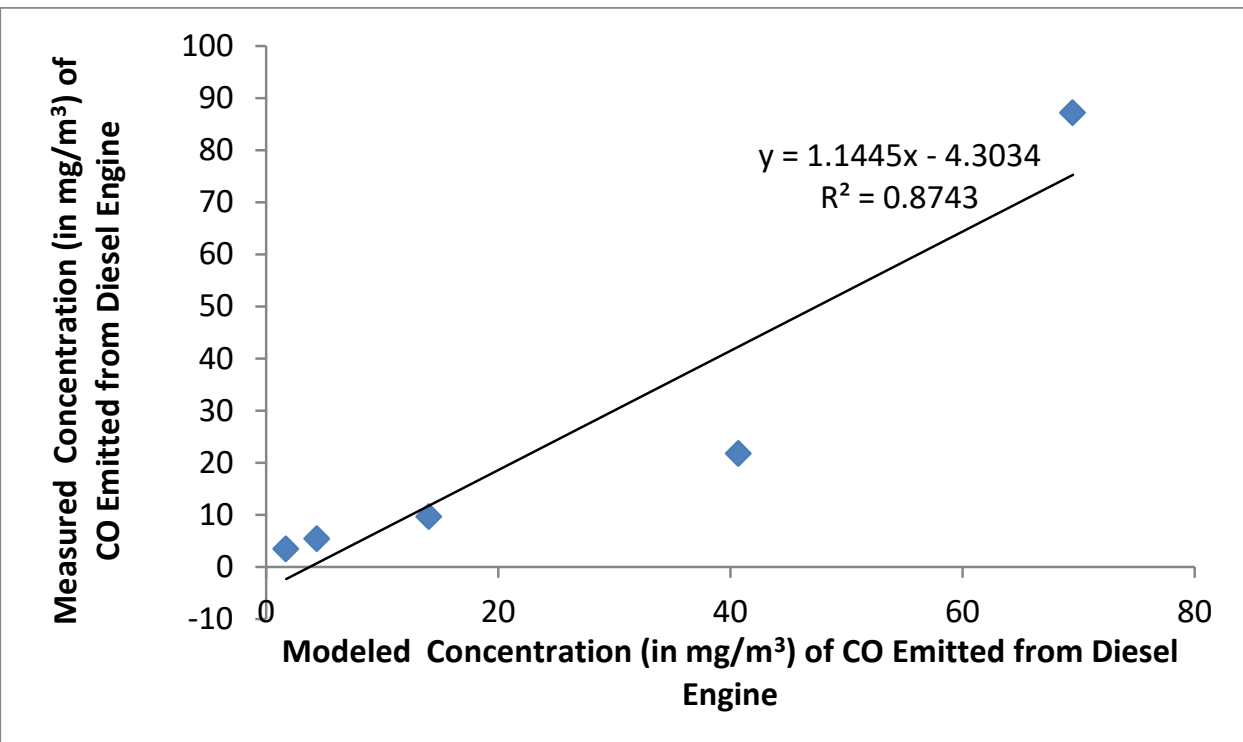

Fig. 9a: Measured and Modeled Concentrations of CO Emitted from $12 \mathrm{Hp}$ Diesel Engine

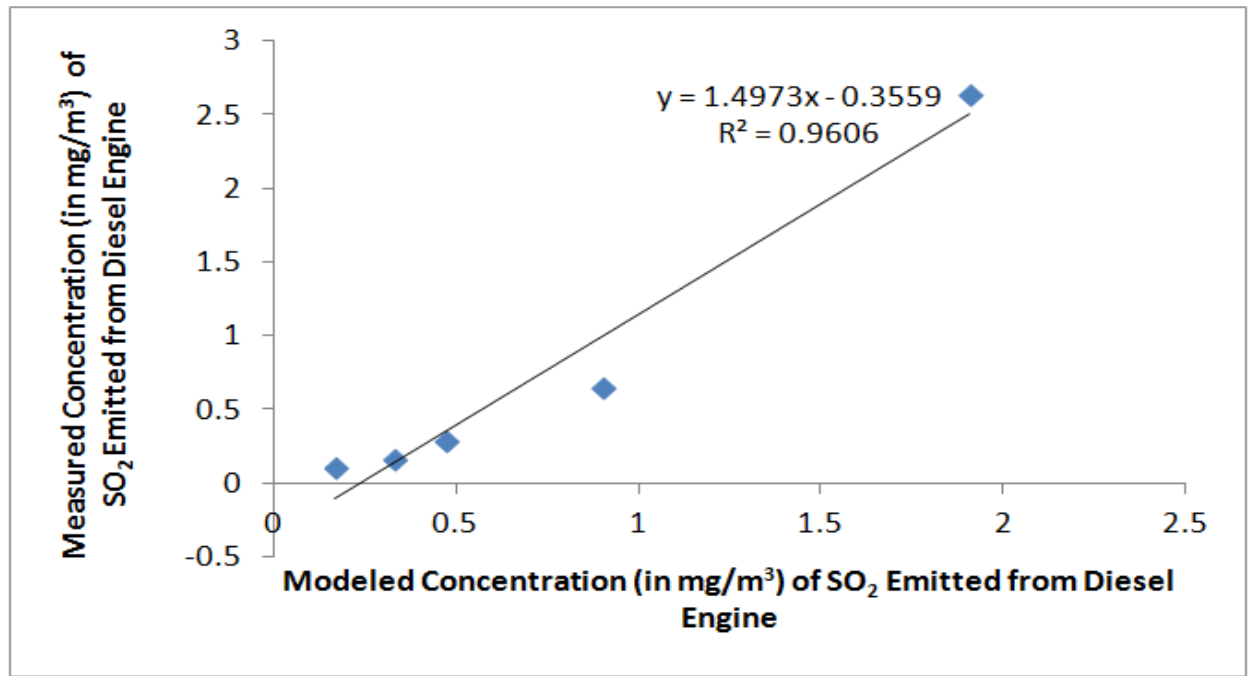

Fig. 9b: Measured and Modeled Concentrations of $\mathrm{SO}_{2}$ Emitted from $12 \mathrm{Hp}$ Diesel Engine

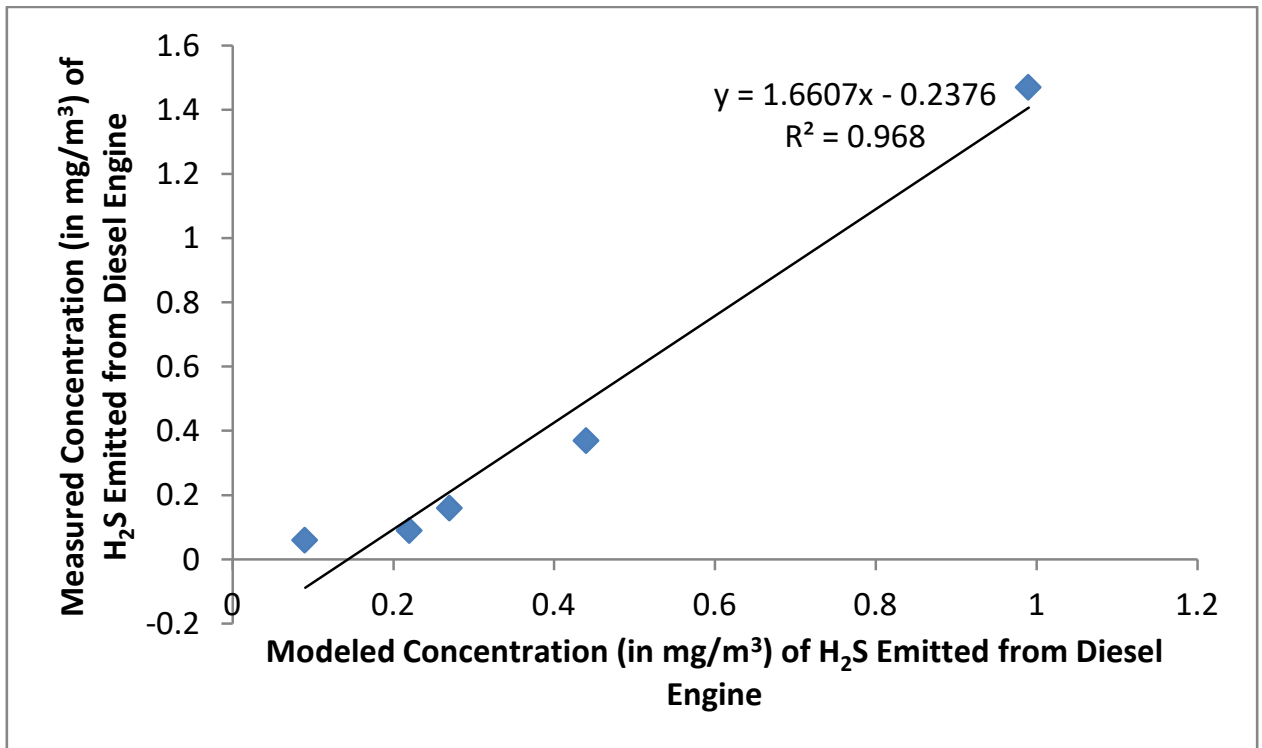

Fig. 9c-Measured and Modeled Concentrations of $\mathrm{H}_{2} \mathrm{~S}$ Emitted from $12 \mathrm{Hp}$ Diesel Engine 


\section{List of Symbols}

\begin{tabular}{|l|l|}
\hline SYMBOL AND ABBREVIATION & MEANING \\
\hline $\mathrm{MK}$ & Makurdi \\
\hline $\mathrm{LF}$ & Lafia \\
\hline$\sigma$ & Standard Deviation \\
\hline $\mathrm{CO}$ & Carbon (II) oxide \\
\hline $\mathrm{SO}_{2}$ & Sulphur (IV) oxide \\
\hline $\mathrm{H}_{2} \mathrm{~S}$ & Hydrogen sulphide \\
\hline $\mathrm{mg} / \mathrm{s}$ & Milligramme per second \\
\hline $\mathrm{mg} / \mathrm{m}^{3}$ & Milligramme per meter cube \\
\hline $\mathrm{Std} . \mathrm{dev}$. & Standard Deviation \\
\hline Var. & Variance \\
\hline Min. & Minimum \\
\hline Max. & Maximum \\
\hline $\mathrm{N}$ & No of monitoring \\
\hline $\mathrm{Hp}$ & Horse power \\
\hline $\mathrm{RG}$ & Range \\
$\mathrm{MSD}$ & Measured Concentration \\
$\mathrm{MDL}$ & Modeled Concentration \\
$\mathrm{X}(\mathrm{m})$ & Downwind Distance (Metre) \\
\hline & \\
\hline
\end{tabular}

\section{References}

[1]. Adel A. Abdel-rahman, (2008). On the Atmospheric Dispersion and Gaussian Plume Model. 2nd International Conference on Waste Management, Water Pollution, Air Pollution, Indoor Climate (WWAI'08) Corfu, Greece, October 26-28, 2008, Pp. 31-39

[2]. Anno (2013): Methodologies for the evaluation of spatial representativeness of air quality monitoring stations in Italy. Pubblicazioni / Energia Ambiente e Innovazione / Anno 2013 / n. 1-2 gennaio-aprile 2013.

[3]. Antonacci Gianluca (2005): Air pollution modeling over complex topography. Doctoral Thesis in Environmental Engineering (XV1 cycle). Faculty of Engineering, University of Trento. Pg. 88-99.

[4]. Antonio Piersanti, Gaia Righini, Felicita Russo, Guiseppe Gemona, Lina Vitali, Luisella Ciancerella (2013). Spatial Representativeness of Air Quality Monitoring Stalations in Italy, (Intalian Ministry). Air Quality Laboratory, National Agency for New Technologies, Energy and Sustainable Economic Development (ENEA), Bologna, Italy

[5]. Akpinar E.K and Akpinar S., An assessment on seasonal analysis of wind energy characteristics and wind turbine characteristics. Energy Convers Manage, 46 (2005):1848-67.

[6]. Belušić, A., Herceg-Bulić, I. and Bencetić Klaić, Z. (2015). Using a generalized additive model to quantify the influence of local meteorology on air quality in Zagreb. Geofizika. 32, 47-77.

[7]. Chambers, S. D., Williams, A. G., Crawford, J. and Griffiths, A. D. (2015a). On the use of radon for quantifying the effects of atmospheric stability on urban emissions. Atmos. Chem. Phys. 15, 1175-1190.

[8]. Daly, A. and Zannetti, P. (2007). An Introduction to Air Pollution-Definitions, Classifications, and History. Chapter 1 of Ambient Air Pollution, The Arab School for Science and Technology (ASST)

[9]. Dede , L. (2008). Adaptive and Reduced Basis Methods for Optimal Control Problems in Environmental Application. Doctoral School (Ph.D.) in Mathematical Engineering, XX cycle. Department of Mathematics, Polytechnic of Milano. Pg.10

[10]. Duc Luong Nguyen (2014). A brief Review of Air Quality Models and their Applications. Open Journal of Atmospheric and Climate Change. Vol.1, Number 2. Pp. 60-80

[11]. European Environment Agency (EEA) (2016). Dispersal of Air Pollutants. A publication of Air and Health

[12]. Fischer, H.B., List E.J., Koh, R.C.Y., Imberger, J. \& N.H. Brooks. (1979): "Mixing in Inland and Coastal Waters" Academic Press, San Diego, CA, 483pp.

[13]. Russel A.G. (1988). Mathematical Modeling of the Effects of Emissions Sources on Atmospheric Pollutant Concentrations; Air Pollution, the Automobile, and Public Health. National Academy Press, Washington DC, Pg.161-205

[14]. Bingheng C. and Haidong K., Air pollution and population health; a global challenge. Environmental Health and preventive Medicine, Vol.13 (2) (2008); 94-101

[15]. Briggs, G.A., (1972): "Discussion: chimney plumes in neutral and stable surroundings"

[16]. Gökçek M, Bayülken A, and Bekdemir S, Investigation of wind characteristics and wind energy potential in Kirklareli, Turkey, Renew Energy; 32(2007a):1739-52.

[17]. Grundstrom, M., Tang, L., Hallquist, M., Nguyen, H., Chen, D. and co-authors. (2015). Influence of atmospheric circulation patterns on urban air quality during the winter. Atmos. Pollut. Res. 6, 278-285.

[18]. IARC (2015): Outdoor Air Pollution: IARC Monographs on the Evaluation of Carcinogenic Risks to humans; Vol.109, 35-109.

[19]. IARC (2013a). Diesel and Gasoline Engine Exhausts and Some Nitroarenes. IARC Monogr Eval. Carcinog Risks Hum, 105:1-704

[20]. Jay A. Farell, John Murlis, Xuenzhu Long, Wei Li and Ring T. (2002). Filament-Based Atmospheric Dispersion Model to Achieve Short Time-scale structure of Odor Plumes. Environmental Fluid Mechanics. 2; 143-169

[21]. Neil E Klepeis, Wayne R Ott, Paul Switzer (2007). Real-time Measurement of outdoor Tobacco Smoke Particles, Journal of the Air and Waste Management Association; Vol.57, Issue 5, Pp.522-534

[22]. Perrino, C., Catrambone, M. and Pietrodangelo, A. (2008). Influence of atmospheric stability on the mass concentration and chemical composition of atmospheric particles: a case study in Rome, Italy. Environ. Int. 34, 621-628

[23]. Turner, D.B., "Workbook of Atmospheric Dispersion Modeling" U.S. Department of Health, Education and Welfare, Public Health Service Publication No. 999-AP-26; (1970) 96pp.

[24]. Ucar A and Balo F., Evaluation of wind energy potential and electricity generation at six locations in Turkey. Appl Energy;86 (2009):1864-72. 